\title{
The Effect of E-Learning on Students' Learning Interest in the Equivalence Education Program
}

\author{
Imam Shofwan $^{1 *}$, Siti Aminatun ${ }^{1}$, Eko Handoyo ${ }^{1}$, Mustasyfa Thabib Kariadi ${ }^{2}$ \\ ${ }^{1}$ Universitas Negeri Semarang, Indonesia \\ ${ }^{2}$ Universitas Jenderal Soedirman, Indonesia \\ *Email: ishofwan@mail.unnes.ac.id
}

Submitted: 25 September 2020. Revised: 13 November 2020. Accepted: 13 February 2021

\begin{abstract}
The Equivalence Education Program is non-formal education that applies learning with the e-learning system to substitute conventional learning in formal education school. This study aims to identify and analyze (1) e-learning conducted by students, (2) students 'interest in learning, and (3) the effect of e-learning on students' learning interest in the Package C Equivalence Program at PKBM Pioneer Karanganyar. The method used is a quantitative approach focusing on the ex post facto approach. The research sample was 45 students of Package C at PKBM Pioneer Karanganyar, out of a total population of 141 Package C students. The data were collected using questionnaire and documentation. The analysis technique used is statistical and inferential analysis techniques focusing on simple linear regression analysis techniques. The results showed that (1) Package C students at PKBM Pioneer Karanganyar appreciated that the e-learning was equivalent to online learning (2) Package C students at PKBM Pioneer Karanganyar had high learning interest, (3) there was a positive influence and e-learning was significant for students' interest in learning in the Package C Program at PKBM Pioneer Karanganyar. The benefit of this research is to provide an overview of online learning that is fun to students.
\end{abstract}

Key words: E-Learning, students' learning interest, equivalence education, non-formal education

How to Cite: Shofwan, I., Aminatun, S., Handoyo, E., \& Kariadi, M. T. (2021). The Effect of E-Learning on Students' Learning Interest in the Equivalence Education Program. Journal of Nonformal Education, 7(1), 103-111.

DOI: http://dx.doi.org/10.15294/jne.v7i1.29276

\section{INTRODUCTION}

Education is a factor that affects the progress of a nation in preparing sufficient provisions for human resources to become qualified and useful human beings (Widodo, 2015). There are three educational paths to prepare quality human beings in Indonesia, namely as stipulated in the National Education System Law No. 20 of 2003 article 13 paragraph 1 concerning formal education, non-formal education and informal education. One of the education channels applied in Indonesia is non-formal education. Nonformal education is education whose reach is outside the school which leads to a comprehensive and equitable education (Kamil, 2011). This education is expected to be able to provide educational services for all groups ranging from the basic level including education for school age children to alternative programs to serve youth and adults and even the elderly. Supported by the National Education System Law No. 20 of 2003 article 5 paragraph 5 concerning the opportunity of citizens who have the right to improve lifelong education. This makes non-formal education programs very broad in scope (Shofwan, Tri, et al., 2019). For example providing solutions to the problem of children not going to school (dropping out / dropping out of school), home schooling (homeschooling), and others with the equality of Equivalence Education Program at the Center for Public Learning Activities (PKBM) (Hermawan, 2012).
The program in the National Equivalence Education Program is divided into three, namely Package A (equivalent to Elementary education), Package B (equivalent to Junior High education), and Package C (equivalent Senior High education) (Kamil, 2011: 96). One of the Equivalence Education Programs applied in Indonesia is Package C program which is equivalent to Senior High education. Students who participate in the Package $\mathrm{C}$ program are from different background as they do not have the opportunity to take formal education, are dropped-out students, adults who are already working, and others (Ernawati \& Mulyono, 2017). BPS data shows that in 2019 the School Participation Rate (APS) for vulnerable people aged 16-18 was $72.36 \%$ while for those aged 1924 was $25.21 \%$. So that it is apparent that at the age of Senior High, there were many students who did not experience high school education and most of them participated in non-formal education such as the Package C Equivalence Education Program.

As it is well known that the Equivalence Education Program has the same role as formal education, so the applied learning system is almost similar. It then can be assumed that the problems that arise in equivalence education are not different. Problems experienced by students or learning society are an indication of the ineffective learning factors of students; it could be that students themselves do not feel motivated and have low interest in learning participation (Laksono, Y. S., Ariyanti, G., \& Santoso, 2016). 
Learning interest is the level of enthusiasm and activeness of students because of high curiosity in learning activities (Putrayasa et al., 2014). In addition, the long duration of study also contributes to problems in education in Indonesia as it is considered ineffective (Suroto, 2014).

Considering the different backgrounds of students, learning conducted in the Package $\mathrm{C}$ tends to be more flexible because of the various activities of students such as working students. The learning system with the previous tradition, namely conventional (face-toface) learning which is dominated by lectures, is less innovative and the low creativity of the teachers causes the lesson to be monotonous and seems boring (Gani, 2015). Most educators tend to provide lessons that emphasize low-level cognitive aspects such as remembering, memorizing, and accumulating information (Sa'ud, 2014) because education has reduced its meaning to a memorization process that leads to the expertise in taking exams (Shofwan \& Kuntoro, 2014).

The development of communication and information technology has opened up great opportunities to be used in various fields of life, one of which is in the field of education (Herlinah, 2014). Quality future generation will be formed if human resources can carry out education to master technological tools that are relevant to today's developments, one of which is e-learning. (Sutarto et al., 2021). The tradition of face-to-face learning or conventional learning has been transferred to blended learning, namely mixed learning in face-to-face integration (Siswati et al., 2020). The COVID-19 pandemic encourages learning with digital technology called e-learning to be better than conventional learning (Siswati et al., 2020).

In addition, e-learning is a process that includes electronic equipment to facilitate learners from distance (Imam Shofwan et al., 2019). Another opinion supports that e-learning is a distance electronic learning process conducted without face to face and does not necessary to be in the same space and at the same time so it is more effective and efficient (Iskandar et al., 2014). According to Chang (2016:476) e-learning is interactive learning focused on integrated elearning and face-to-face learning to ensure that the learning process can stimulate students' interest, report learning progress, have tutors to provide feedback and guide students to the expected targets.

The use of social and digital media is a necessity that is integrated in the daily lives of young people based on 2016 data from the 2016 Research and Development Agency for Kominfo (Utami, Undang, \& Wahyudi, 2017: 78). This study shows that $98 \%$ of children and adolescents surveyed know about the internet and $79.5 \%$ of them are internet users. This means that the rest are adults, some of whom are familiar with internet technology. Technology that is currently developing, such as the internet, has become a part of everyday life for school age children. So, this is no longer something foreign to society, especially adolescents to adulthood.

The Community Learning Activity Center or PKBM Pioneer Karanganyar is one of the PKBM in Indonesia implementing e-learning as a substitute for conventional learning. The application used in learning is the online equivalence created by the Ministry of Education and Culture (Astuti et al., 2019). By elearning students do not need to come to PKBM to take part in learning. They only need to register, then access the learning materials provided and adjust the instructions from the tutor from their respective places. Space and time are no longer obstacles for those who have activities such as work and others. Students can take part in learning based on their free time so that it is more flexible (Hewett et al., 2019).

The purpose of this study was to find out about elearning of the Package $\mathrm{C}$ students at PKBM Pioneer Karanganyar, students' interest in the Package $\mathrm{C}$ at PKBM Pioneer Karanganyar, the effect of e-learning on students' interest in learning in the Package $\mathrm{C}$ at PKBM. Pioneer Karanganyar, and how much the influence of e-learning contributes to students' interest in learning in the Package $\mathrm{C}$ at PKBM Pioneer Karanganyar. This is based on previous research which stated that e-learning had an influence on interest in learning, because the development of science and technology gives rise to e-learning which makes learning interactive and effective. (Oktarika, 2015).

\section{METHOD}

This research is designed with a quantitative research approach that focuses on ex post facto, namely research carried out to examine events that have already occurred (Darmadi, 2014: 43). This means that the students' interest in learning the Package $\mathrm{C}$ already exists because of the existence of e-learning as learning implemented in PKBM Pioneer Karanganyar, so data manipulation cannot be done. This research was conducted at PKBM Pioneer Karanganyar with a vulnerable time of approximately one month. The population of this study was 141 students of the Package C consisting of 19 students of class C10, 30 students of class C11, and 92 students of class C12. There were 45 students as sample from the existing class obtained through the sampling technique, namely proportionate stratified random sampling.

The data collection techniques used in this study were documentation and questionnaires. Documentation is used to obtain student data and e-learning is conducted. Questionnaire technique is a way of collecting data by giving a set of questions or statements 
in writing to respondents to respond according to circumstances (Sugiyono, 2018: 142). Respondents choose answers from the statements that are already available on the questionnaire according to the circumstances of each respondent. The data analysis technique used was descriptive statistical analysis to find out about e-learning and student interest in the Package $\mathrm{C}$ at PKBM Pioneer Karanganyar and inferential statistical analysis techniques that are focused on simple linear regression analysis to test the effect of e-learning on participants' learning interest of students in the Package C program at PKBM Pioneer Karanganyar. Hypothesis testing is done by comparing $t$ count and $t$ table and comparing the significance result and significance value.

The instrument used to compile this questionnaire was based on research variables, namely the independent variable (e-learning) and the dependent variable (interest in learning). The questionnaire regarding e-learning was prepared based on the measurement aspects of indicators, namely learning materials, online evaluation, online discussions, online tutors, and multimedia. The interest in learning questionnaire was based on indicators namely pleasure, interest, attention, participation, and desire/awareness. Based on the indicators of this study, 23 statements were obtained with 13 statements for measurement aspects of e-learning and there were 10 statements for measurement aspects of learning interest which had previously been tested for validity and reliability so that they were worthy of use in this research.

\section{RESULTS AND DISCUSSION}

This study was conducted by distributing questionnaires to 45 respondents, namely students of Package C program at PKBM Pioneer Karanganyar obtained by using proportionate stratified random sampling technique. This research questionnaire consisted of 23 statements with 13 statements regarding e-learning and 10 statements regarding interest in learning. The scale used in this study was a Likert scale, where there were five answer options. Table 1 below shows the questionnaire answer scores that were used in this study.

Table 1. Questionnaire Answer Scores

\begin{tabular}{ccc}
\hline Abbreviation & Answer & Score \\
\hline HA & Highly Agree & 5 \\
A & Agree & 4 \\
SDA & Slightly Disagree & 3 \\
DA & Disagree & 2 \\
HAD & Highly Disagree & 1 \\
\hline
\end{tabular}

The statements used in this study have passed the validity and reliability test. The results of the validity calculation show that there are 23 valid statements that have met the criteria, namely the value exceeds 0.444 . Reliability results show that the statement is classified as good for the e-learning variable because the value exceeds $0.8(0.898)$ and the interest in learning variable is considered acceptable because the value is equal to or above $0.7(0.737)$, so that the statement in the study is reliable. These results indicated that the statements put forward in the study can be used to measure the effect of e-learning on students' learning interest in the Package $\mathrm{C}$ program at PKBM Pioneer Karanganyar.

The analysis technique of this research uses descriptive statistical analysis techniques and simple linear regression analysis techniques. The reason is because this research includes parametric statistics, in which a prerequisite test should be done first. The prerequisite test was carried out to test the respondent's data on the answers to the statements on the questionnaire with the help of the IBM SPSS v.22 program. There are three tests in prerequisite testing, namely (1) the normality test to determine whether the data is normally distributed or not (Priyatno, 2010), (2) heteroscedasticity test to prove there is no heteroscedasticity problem (similarity of variants) (Priyatno, 2010), and (3) linearity test to determine whether the relationship is linear or not (Kasmadi \& Sunariah, 2016).

The result of the prerequisite test calculation proves that the research includes parametric statistics, because normally distributed data is calculated using the Kolmogorov-Smirnov $\mathrm{Z}$ method, there is no heteroscedasticity problem through the Spearman's rho test, and linear data is based on the calculation of the Compare Means method. The calculation results of the prerequisite test are presented in Table 2 .

Table 2. Prerequisite Test Calculation Results Normality Test, Kolmogorov- Smirnov Z Method One-Sample Kolmogorov-Smirnov Test

\begin{tabular}{|c|c|}
\hline & $\begin{array}{l}\text { Unstandardized } \\
\text { Residual }\end{array}$ \\
\hline$\overline{\mathrm{N}}$ & 45 \\
\hline Normal Parameter-Mean & .0000000 \\
\hline $\begin{array}{l}\text { Std. Devia } \\
\text { tion }\end{array}$ & 2.42534136 \\
\hline Most Extreme Dif-Absolute & .100 \\
\hline Positive & .080 \\
\hline Negative & -.100 \\
\hline Test Statistic & .100 \\
\hline Asymp. Sig. (2-tailed) & $.200^{\mathrm{c}, \mathrm{d}}$ \\
\hline
\end{tabular}

a. Test distribution is Normal. 
b. Calculated from data.

c. Lilliefors Significance Correction.

d. This is a lower bound of the true significance.

Heteroskedasticity Test, Spearman's rho Test Correlations

\begin{tabular}{|c|c|c|c|c|}
\hline & \multicolumn{2}{|c|}{ UnstandardizedE- } \\
\hline & & & Residual & learning \\
\hline \multirow{7}{*}{\multicolumn{2}{|c|}{$\begin{array}{l}\text { Spearman'sUnstandard } \\
\text { rho } \\
\text { rhesidual }\end{array}$}} & Correlation & & 073 \\
\hline & & Coefficient & 1.000 & .073 \\
\hline & & Sig. (2-tailed) & & .633 \\
\hline & & $\mathrm{N}$ & 45 & 45 \\
\hline & & $\begin{array}{l}\text { Correlation } \\
\text { Coefficient }\end{array}$ & .073 & 1.000 \\
\hline & & Sig. (2-tailed) & .633 & \\
\hline & & $\mathrm{N}$ & 45 & 45 \\
\hline
\end{tabular}

Linearity Test, Compare Means Method ANOVA Table

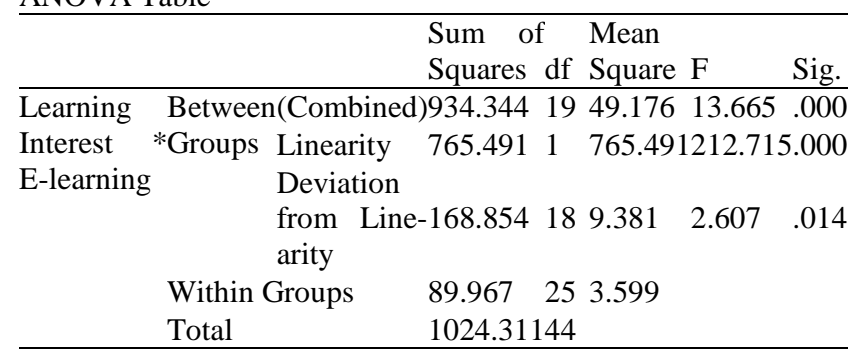

The first analysis technique is descriptive statistical analysis technique. The result of the calculation of descriptive statistical analysis is to find out or describe the e-learning and learning interest of students taking Package $\mathrm{C}$ program at PKBM Pioneer Karanganyar. These results are obtained through respondents' answers to the questionnaire. Table 3 shows the results of descriptive statistical analysis.

Table 3. Descriptive Statistical Analysis Results Descriptive Statistics

\begin{tabular}{lccc}
\hline \multicolumn{4}{c}{ N RangeMinimumMaximum Sum Mean $\begin{array}{l}\text { Std. De- } \\
\text { viation }\end{array}$} \\
\hline $\begin{array}{l}\text { E- } \\
\text { learning }\end{array} 4536$ & 29 & 65 & 247254.936 .665 \\
$\begin{array}{l}\text { Learning } \\
\text { Interest }\end{array}$ & 27 & 50 & 183440.764 .825 \\
$\begin{array}{l}\text { Valid N } \\
\text { (listwise) }\end{array}$ & & & \\
\hline
\end{tabular}

\section{E-Learning on Package C Program at PKBM Pio- neer Karanganyar}

E-learning is used as a learning innovation that is carried out using an online equivalence (Lai et al., 2016), especially for students participating in Package $\mathrm{C}$ at PKBM Pioneer Karanganyar. The existence of e-learning in the world of education, namely to overcome various obstacles between educators and students, in this case is the constraints of limited location and time limitations (Anggraini, 2018: 99). This adapts to the circumstances of students with various backgrounds. Online learning with e-learning, both educators and students do not need to meet physically to carry out learning (Eddy \& Suryono, 2019). Although educators are busier because they have to prepare e-learning (Shofwan, Sugiarti, et al., 2019) and also have to master technology.

The calculation of e-learning in the Package $\mathrm{C}$ program at PKBM Pioneer Karanganyar shows the mean of 54.93, which means that it is in good criteria. This means that students participating in the Package $\mathrm{C}$ at PKBM Pioneer Karanganyar appreciate the learning services with e-learning using online equivalence. The results of the calculation of the descriptive analysis of the e-learning variables are presented in Table 4 below.

Table 4. Descriptive Analysis of E-Learning Variables

\begin{tabular}{lllll}
\hline No & Interval & Frequency & Percentage & Criteria \\
\hline 1. & $56-65$ & 19 & $42.22 \%$ & Very Good \\
2. & $46-55$ & 25 & $55.56 \%$ & Good \\
3. & $35-45$ & - & $0.00 \%$ & Slightly \\
& & & & Poor \\
4. $\quad 24-34$ & 1 & $2.22 \%$ & Poor \\
$5 . \quad 13-23$ & - & $0.00 \%$ & Very Poor \\
Total & 45 & $100 \%$ & \\
Average & & & 54.93 \\
Criteria & & & Good \\
\hline
\end{tabular}

Students participating in the Package $\mathrm{C}$ at PKBM Pioneer Karanganyar appreciated the implementation of learning through e-learning because the learning materials can be saved in their smartphone or laptop, so it is more flexible and simple. In addition, the existence of online evaluations in e-learning provides opportunities for students to sharpen their ability to more serious in completing the assignments (Florjan, 2015). The availability of online tutors has the role of educators in online learning (Siswanto et al., 2018). Online discussions were carried out in order to increase students' insights and curiosity. E-learning is also provided with multimedia, one of which is a video which makes the material delivered more interestingly (Mulyadi et al., 2020). In accordance with the statement that Multimedia material contents illustrate the richness and diversification that combine sound, image, picture and words (H. Lin, Chen, \& Nien, 2014: 422).

From the distributed questionnaires the respondents' answers in the form of a percentage of the answers to each indicator are presented in Table 5. 
Table 5. Descriptive Indicator of E-Learning Variables

\begin{tabular}{llll}
\cline { 1 - 2 } No & Indicator & Average & Percentage \\
\cline { 1 - 2 } 1. & Learning Material & 195 & $20.5 \%$ \\
2. & Online Evaluation & 193 & $20.3 \%$ \\
3. & Online Discussion & 186 & $19.6 \%$ \\
4. & Online Tutors & 191.33 & $20.1 \%$ \\
5. & Multimedia & 185.5 & $19.5 \%$ \\
\multicolumn{2}{l}{ Total } & 950.3 & $100 \%$ \\
\hline
\end{tabular}

Table 5 pinpoints that the highest e-learning is found in the learning material indicator of $20.5 \%$ with an average of 195 . E-learning with online learning material makes learning more flexible for students of the Package $\mathrm{C}$ at PKBM Pioneer Karanganyar, most of which have activities such as work, so the existence of learning materials that can be saved on smartphones, laptops, or other online learning tools makes it easier for them learn (Glowatz et al., 2018). Therefore, the existence of e-learning implemented in PKBM Pioneer Karanganyar through an online equivalence application provides great opportunities for students participating in the Package $\mathrm{C}$ to be able to follow learning wherever they are and whenever they can open it without being constrained by location and time.

\section{Students' Learning Interest in the Package C Pro- gram at PKBM Pioneer Karanganyar}

Learning interest is an inner impulse that arises from students to improve learning habits based on the influencing trigger indicators (Lestari, 2015: 117). So that the existing interest in the individual will be the impetus for taking an action through certain efforts (Siswanto, 2016: 15). A strong interest in learning will make actions conducted with persistence, seriousness and sincerity, and not easily give up. Vice versa, if the interest in learning is low, then the action will conducted lazily, carelessly, and without passion.

The results of the calculation of descriptive statistical analysis in Table 3 show that the mean resulted by the interest in learning as the dependent variable is 40.76. So it can be concluded that the average learning interest of students participating in the Package $\mathrm{C}$ at PKBM Pioneer Karanganyar is high. This can be seen in the following Table 6 .

The learning interest of students participating in the Package $\mathrm{C}$ at PKBM Pioneer Karanganyar grew the most because of the sense of interest which amounted to $20.8 \%$. In accordance with Baharudin's opinion (Pasaribu, D. S., Hendri, M., \& Susanti, N. Karim, 2017: 63) that students who have interest will be interested in learning so that they become enthusiastic, are easy to accept the lesson, and are serious in learning something.
Table 6. Descriptive Analysis of Learning Interest Variable

\begin{tabular}{lllll}
\hline No & Interval & Frequency & Percentage & Criteria \\
\hline 1. & $43-50$ & 13 & $28.89 \%$ & Very High \\
2. & $35-42$ & 27 & $60 \%$ & High \\
3. & $27-34$ & 5 & $11.11 \%$ & Medium \\
4. & $19-26$ & - & $0.00 \%$ & Low \\
5. $\quad 10-18$ & - & $0.00 \%$ & Very Low \\
Total & 45 & $100 \%$ & \\
Average & & & 40,76 \\
Criteria & & & High \\
\hline
\end{tabular}

Other than being attracted, interest in learning arises because of the desire/awareness of the need to learn science, the attention given to learning (Hazizah \& Ismaniar, 2020), the joy that comes from within, and the form of participation provided by students. The percentage distribution of indicators of the learning interest variable of students of the Package $\mathrm{C}$ at PKBM Pioneer Karanganyar is presented in Table 7 below.

Table 7. Descriptive Indicator of Learning Interest Variable

\begin{tabular}{llll}
\hline No & Indicator & Average & Percentage \\
\hline 1. & Feeling of Pleasure & 180 & $19.7 \%$ \\
2. $\quad$ Interest & 190 & $20.8 \%$ \\
3. & Attention & 181 & $19.8 \%$ \\
4. $\quad$ Participation & 179 & $19.5 \%$ \\
5. Desire/Awareness & 184.67 & $20.2 \%$ \\
Total & 914.67 & $100 \%$ \\
\hline
\end{tabular}

The high interest in learning of the Package $\mathrm{C}$ students at PKBM Pioneer Karanganyar means that the learning conducted gives positive effect to students. The accuracy of learning so that it raises interest in learning makes learning easily accepted and even applied in life (Alebaikan \& Troudi, 2017). The Package C students at PKBM Pioneer Karanganyar, in addition to participating in learning, also develop abilities according to existing technological advances. Because learning is considered effective and successful when students become active in learning to form certain insights, skills, and behaviors (Ekosiswoyo \& Sutarto, 2015: 36).

\section{The Influence of E-Learning on Learning Interest in the Package C Program at PKBM Pioneer Ka- ranganyar}

This research then uses inferential statistical analysis techniques. Several conditions that must be met in inferential statistical analysis techniques are the prerequisite test. The prerequisite test consists of the normality test, heteroscedasticity test and linearity test. The results of this test have been presented in Table 2 and show that all the results meet the re- 
quirements, so that it can be carried out for the next test, namely inferential statistical analysis which focuses on simple linear regression analysis techniques.

The hypothesis test is conducted prior to performing a simple linear regression analysis. Hypothesis testing according to Kasmadi \& Sunariah (2016: 121) is the basis for determining whether there is a relationship between variables. There are two hypotheses in this study, namely:

$\mathrm{Ha}: \mathrm{b} \neq 0$

The working hypothesis $(\mathrm{Ha})$ is that there is an effect of e-learning on students' interest in learning in the Package $\mathrm{C}$ program at PKBM Pioneer Karanganyar.

$\mathrm{HO}: \mathrm{b}=0$

The null hypothesis (HO) is that there is no effect of e-learning on students' learning interest in the Package $\mathrm{C}$ program at PKBM Pioneer Karanganyar.

The method used in testing this hypothesis is to compare the $t$ value with the $t$ table and by comparing the significance value with a predetermined significance level. The following is presented in Table 8 regarding the results of the calculation of hypothesis testing.

Table 8. Hypothesis Test Results Coefficientsa

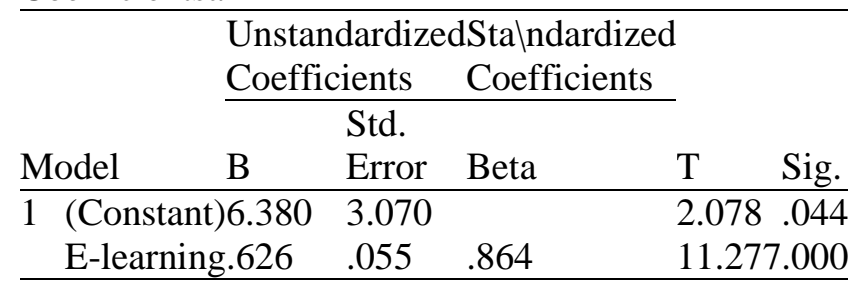

a. Dependent Variable: Learning Interest

Based on Table 8, it is known that the t value is 11.277, which means that the result is greater than the $\mathrm{t}$ table, because the $\mathrm{t}$ table is obtained through $\alpha=$ 0.05 and df $43=2.201$. So it is concluded that HO is rejected and $\mathrm{Ha}$ is accepted, or there is an effect of elearning on students' learning interest in the Package $\mathrm{C}$ program at PKBM Pioneer Karanganyar. In addition, the significance value shows a result of 0.000 , where for the terms if the significance value $<0.05$ significance level means that $\mathrm{HO}$ is rejected and $\mathrm{Ha}$ is accepted or there is a significant influence between elearning on students' learning interest in the Package $\mathrm{C}$ program at Pioneer PKBM. Karanganyar.

A simple linear regression analysis technique was carried out in order to determine the effect of the independent variable, namely e-learning, on the dependent variable, namely the learning interest of students in the Package C program at PKBM Pioneer Karanganyar. The following is presented in Table 9 regarding the results of calculating simple linear regression analysis.
Table 9. Simple Linear Regression Analysis Results

Variables Entered/Removed ${ }^{\mathrm{a}}$

\begin{tabular}{llcc}
\hline Model & $\begin{array}{l}\text { Variables } \\
\text { tered }\end{array}$ & $\begin{array}{c}\text { En-Variables } \\
\text { moved }\end{array}$ & $\begin{array}{c}\text { Re- } \\
\text { Method }\end{array}$ \\
\hline 1 & E-learning & . & Enter \\
\hline
\end{tabular}

a. Dependent Variable: Learning Interest

b. All requested variables entered.

Model Summary ${ }^{\mathrm{b}}$

\begin{tabular}{|c|c|c|c|}
\hline Model R & R Square & $\begin{array}{l}\text { Adjusted } \\
\text { Square }\end{array}$ & $\begin{array}{l}\text { RStd. Error of } \\
\text { the Estimate }\end{array}$ \\
\hline $.864^{\mathrm{a}}$ & 747 & .741 & 2.453 \\
\hline
\end{tabular}

a. Predictors: (Constant), E-learning

b. Dependent Variable: Learning Interest

ANOVA $^{\mathrm{a}}$

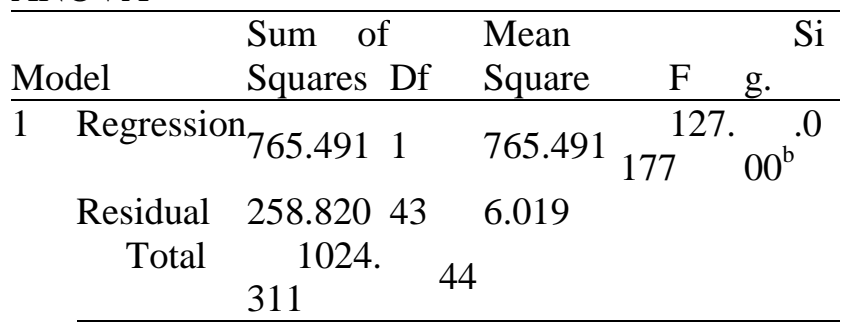

a. Dependent Variable: Learning Interest

b. Predictors: (Constant), E-learning

Coefficients $^{\mathrm{a}}$

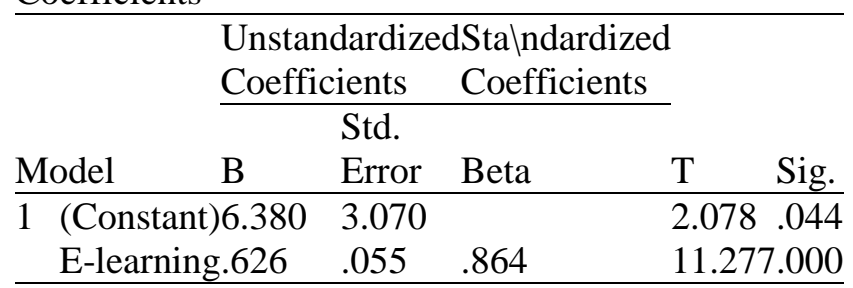

a. Dependent Variable: Learning Interest

Based on Table 8, the coefficients obtained a significant result of 0.000 which is $<0.05$, indicating that the effect of e-learning on students' learning interest in the Package $\mathrm{C}$ program at PKBM Pioneer Karanganyar is significant. So there is a significant influence between the independent variable and the dependent variable. In addition, it is also known that the regression coefficient is positive, namely 0.626 . This shows that e-learning has a positive effect on students' interest in learning in the Package $\mathrm{C}$ program at PKBM Pioneer Karanganyar. The resulting simple regression analysis equation is $\mathrm{Y}^{\prime}=6.380+$ $0.626 \mathrm{X}$.

The results of this study are consistent with previous research entitled "The Effect of Learning Using E-Learning Media on Students' Learning Interest" by Dini Oktarika (2015). The similarity of this study with previous research lies in the calculation of whether there is an effect of using e-learning media 
on interest in learning (El Miedany \& El Miedany, 2018). The result of this study is that there is an effect of using e-learning media on interest in learning.

This study shows the results that the emergence of a response of will or interest due to a stimulus or stimulus. The stimulus that arises in the interest in learning of students in the Package $\mathrm{C}$ program at PKBM Pioneer Karanganyar is the existence of learning with e-learning using online equivalents. This is in accordance with behaviorism learning theory, where learning is a process of changing behavior as a result of students' responses to a stimulus (Nahar, 2015). The relationship between research results and behaviorism learning theory lies in the interest caused by the stimulus. When learning with e-learning using online equivalents is able to provide a high sense of curiosity because the learning provided is good and precise, a response will emerge in the form of a high interest in learning.

Improved learning with e-learning is expected to increase the interest in learning of students participating in the Package $\mathrm{C}$ at PKBM Pioneer Karanganyar. E-learning has made learning easier in the Package C program at PKBM Pioneer Karanganyar. Learning that can be done flexibly whenever and wherever has a great chance followed by students of the chasing program, especially the Package $\mathrm{C}$, where the majority of them are of school age and of working age in average.

\section{CONCLUSION}

Based on the research, it can be concluded that e-learning has a positive and significant effect on interest in learning in the Package $\mathrm{C}$ program at PKBM Pioneer Karanganyar. Most of the e-learning conducted by students in the Package $\mathrm{C}$ program at PKBM Pioneer was due to online learning materials, which amounted to $20.5 \%$ and other indicators, namely online evaluations, online tutors, online discussions, and multimedia. The learning interest that grows in students of the Package $\mathrm{C}$ program at PKBM Pioneer Karanganyar is due to a sense of interest which is $20.8 \%$ and other indicators namely desire/awareness, attention, feelings of pleasure, and participation in learning.

The results showed that there was a positive and significant influence between e-learning and students' interest in learning in the Package $\mathrm{C}$ program at PKBM Pioneer Karanganyar. It is hoped that this positive and significant influence can be used as a reference for education practitioners in order to be able to follow the flow of technological developments in order to be able to provide new innovations in the field of education equally in formal, non-formal and informal education in order to increase students' in- terest in learning. Especially for teachers or tutors, they are expected to have skills in managing elearning professionally through IT-based competency training activities.

\section{REFERENCES}

Alebaikan, R., \& Troudi, S. (2017). Blended learning in Saudi universities: challenges and perspectives. 7769(January).

Anggraini, A. (2018). Keefektifan Pembelajaran Elektronik (E-Learning) Sebagai Pengganti Perkuliahan Konvensional Untuk Meningkatkan Kemampuan Analitis Mahasiswa. Jurnal Sosial Humaniora, 9(2), 95-105.

Astuti, Waluya, S. B., \& Asikin, M. (2019). Strategi Pembelajan Dalam Menghadapi Tantangan Era Revolusi 4.0. Seminar Nasional Pascasarjana 2019, 51-62.

Chang, V. (2016). Review and Discussion: Elearning for Academia and industry. Interntional Journal of Information Management, 36(3), 476485.

Darmadi, H. (2014). Metode Penelitian Pendidikan dan Sosial. Alfabeta.

Eddy, G. S., \& Suryono, Y. (2019). Implementation of Online Learning Lessons in the Package C Program. Journal of Nonformal Education, 5(2), 117124.

Ekosiswoyo, R., \& Sutarto, J. (2015). Model Pembelajaran Pendidikan Kesetaraan Berbasis Keterampilan Vokasional. Journal of Nonformal Education, 1(1), 36-42.

El Miedany, Y., \& El Miedany, Y. (2018). eLearning, Adaptive Learning and Mobile Learning. Rheumatology Teaching, 235-258.

Ernawati \& Mulyono, S. E. (2017). Manajemen Pembelajaran Program Paket C di Pkbm Bangkit Kota Semarang. 3(1), 60-71.

Florjan, V. (2015). Learning Technology for Education in Cloud. 533, 168-180.

Gani, A. (2015). Pengaruh Model Pembelajaran Dan Persepsi Tentang Matematika Terhadap Minat Dan Hasil Belajar Matematika Siswa SMP Negeri Di Kecamatan Salomekko Kabupaten Bone. Jurnal Daya Matematis, 3(3), 337-343.

Glowatz, M., Eds, A. B., Coulson, G., \& Ferrari, D. (2018). e-Learning, e-Education, and Online Training (Vol. 243).

Hazizah, N., \& Ismaniar, I. (2020). Teachers' Strategies in Preparing Online Learning Digital Media for Developing Children's Literacy Skills. Journal of Nonformal Education ', 6(2), 156-160.

Herlinah. (2014). Pengaruh Penggunaan Multimedia Interaktif Terhadap Minat Belajar Mahasiswa Pa- 
da Stmik Handayani Makassar. Jurnal Penelitian Komunikasi Dan Opini Publik, 18(3), 241-254.

Hermawan, I. K. D. (2012). Kinerja Pendidikan Kesetaraan Sebagai Salah Satu Jenis Pendidikan Nonformal. Jurnal Pendidikan Dan Kebudayaan, $18(1), 65-84$.

Hewett, S., Becker, K., \& Bish, A. (2019). Blended workplace learning: the value of human interaction. Education and Training, 61(1), 2-16.

Imam Shofwan, I., Shofwan, I., Desmawati, L., Raharjo, T., \& Widya Santosa, I. (2019). Homeschooling: Nonformal Education Learning Strategy 4.0. 382(Icet), 655-660.

Iskandar, A., Gina, W., \& Cahyono, T. (2014). Pengaruh Transformasi Sistem E-Learning Terhadap Minat Belajar Siswa Sekolah Menengah Kejuruan (SMK) Wikrama Di Kota Bogor. Jurnal KMP (Jurnal Komunikasi Pembangunan), 12(2). https://doi.org/10.29244/jurnalkmp.12.2.

Kamil, M. (2011). Pendidikan Nonformal: Pengembangan Melalui Pusat Kegiatan Belajar Mengajar $(P K B M)$ di Indonesia (Sebuah Pembelajaran dari Kominkan Jepang). Alfabeta.

Kasmadi, \& Sunariah, N. S. (2016). Panduan Modern Penelitian Kuantitatif. Alfabeta.

Lai, M., Lam, K. M., \& Lim, C. P. (2016). Teaching in Higher Education Design principles for the blend in blended learning: a collective case study. 2517(May). https://doi.org/10.1080/13562517.2016.1183611

Laksono, Y. S., Ariyanti, G., \& Santoso, F. G. I. (2016). Hubungan Minat Belajar Siswa Terhadap Prestasi Belajar Matematika Siswa Dalam Pembelajaran Kooperatif Tipe Stad Menggunakan Komik. Jurnal Edukasi Matematika Dan Sains, l(2), 60-64.

Lestari, I. (2015). Pengaruh Waktu Belajar dan Minat Belajar terhadap Hasil Belajar Matematika. Formatif: Jurnal Ilmiah Pendidikan MIPA, 3(2), $115-125$.

Lin, H., Chen, W., \& Nien, S. (2014). The Study of Achievement and Motivation by E-Learning - A Case Study. International Journal of Information and Educational Technology, 4(5), 421-425.

Mulyadi, D., Suryadi, \& Aliyyah, R. R. (2020). Skills Education Program: Is it Beneficial for the Society? Journal of Nonformal Education, 6(2), 101106.

Oktarika, D. (2015). Pengaruh Pembelajaran Menggunakan Media E-Learning Terhadap Minat Belajar. Jurnal Pendidikan Informatika Dan Sains, 4(1), 15-26.

Pasaribu, D. S., Hendri, M., \& Susanti, N. Karim, Y. (2017). Upaya Meningkatkan Minat dan Hasil Belajar Fisika Siswa dengan Menggunakan Model Pembelajaran Talking Stick pada Materi Listrik
Dinamis di Kelas X SMAN Muaro Jambi. Jurnal EduFisika, 2(1), 61-69.

Priyatno, D. (2010). Teknik Mudah dan Cepat Melakukan Analisis Data Penelitian dengan SPSS. Gava Media.

Putrayasa, I. M., Syahruddin, \& Mergunayasa, I. G. (2014). Pengaruh Model Pembelajaran Discovery Learning Dan Minat Belajar Terhadap Hasil Belajar IPA Siswa. Jurnal Mimbar PGSD Universitas Pendidikan Ganesha, 2(1), 1-11.

Sa'ud, U. S. (2014). Inovasi Pendidikan. Alfabeta.

Shofwan, I., \& Kuntoro, S. A. (2014). Pengelolaan Program Pembelajaran Pendidikan Alternatif Komunitas Belajar Qaryah Thayyibah Di Salatiga Jawa Tengah. Jurnal Pendidikan Dan Pemberdayaan Masyarakat, 1(1), 50.

Shofwan, I., Sugiarti, R., Erlangga, E., \& Yogatama, A. (2019). Indicator Of Teacher Work Stress. 8(12), 730-736.

Shofwan, I., Tri, J., Raharjo, A., Rifai, R. C., Fakhruddin, F., Sutarto, J., Utsman, U., Arbarini, M., Suminar, T., Mulyono, S. E., Kisworo, B., Malik, A., Yusuf, A., Ilyas, I., Desmawati, L., Chairul, M., \& Umanailo, B. (2019). Non-Formal Learning Strategy Based On Tahfidz And Character In The Primary School. International Journal of Scientific \& Technology Research, 8(10).

Siswanto, Y. (2016). Pengaruh Minat Belajar terhadap Hasil Belajar Pendidikan Kesetaraan Paket $C$ di UPTD Sanggar Kegiatan Belajar Ungaran. Universitas Negeri Semarang.

Siswanto, Y., Sutarto, J., \& Mulyono, S. E. (2018). Etraining based on Determination of Education and Training Models of Early Childhood Teachers Education Programs. Journal of Nonformal Education, 4(2), 107-118.

Siswati, S., Astiena, A. K., \& Savitri, Y. (2020). Evaluation of Online-Based Student Learning: Models During New Normal Pandemic Covid-19 in Indonesia. Journal of Nonformal Education, 6(2), 148-155.

Sugiyono. (2018). Metode Penelitian Kuantitatif, Kualitatif, $R \& D$. Alfabeta.

Suroto. (2014). Kebijakan Pembangunan Pendidikan Nasional Indonesia dan Kendala yang Dihadapi sebagai Upaya Perbaikan dalam Rangka Mempersiapkan Warga Negara Muda yang Baik dan Cerdas. Jurnal Pendidikan Kewarganegaraan, 4(7), 495-499.

Sutarto, J., Mulyono, Sungkowo, E., \& Shofwan, I. (2021). Determining Factors That Affect the Quality of Process and Training Results of Non-formal PAUD Educators in Indonesia. Elementary Education Online, 20(14), 228-236.

Utami, R., Undang, R., \& Wahyudi, I. (2017). Pengaruh Penggunaan E-Learning dengan 
Imam Shofwan et al. / Journal of Nonformal Education 7 (1) (2021): 103-111

Schoology Materi Gravitasi Newton terhadap Hasil Belajar Siswa. Jurnal Pembelajaran Fisika, $5(2), 81-91$.
Widodo, H. (2016). Potret Pendidikan Di Indonesia Dan Kesiapannya Dalam Menghadapi Masyarakat Ekonomi Asia (MEA). Jurnal Kependidikan Dan Kemasyarakatan, 13(2), 293-308. 